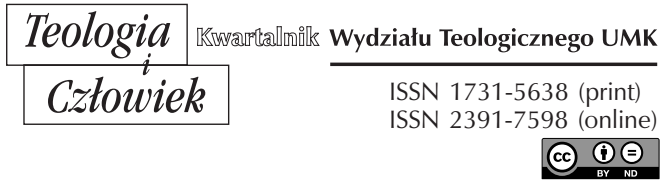

43(2018)3, ss. 47-63

KS. MAREK JODKOWSKI

WYDZIAL TEOLOGICZNY UNIWERSYTETU WARMIŃSKO-MAZURSKIEGO W OLSZTYNIE

KSMAREKJ@WP.PL

ORCID 0000-0001-9793-9935

\title{
DZIAŁALNOŚĆ KOŚCIOłA EWANGELICKIEGO W PRUSACH WSCHODNICH W CZASIE I WOJNY ŚWIATOWEJ
}

DOI: http://dx.doi.org/10.12775/TiCz.2018.026

Streszczenie. W czasie I wojny światowej przed Kościołem ewangelickim stanęły nowe wyzwania. Opieka pastoralna nad wiernymi przestała ograniczać się do animowania życia sakramentalnego i religijnego w parafiach. Ubytek ludności, starty materialne, czy też pogarszająca się sytuacja gospodarcza wygenerowały konieczność zaangażowania Kościoła na rzecz gwałtowanie wzrastającej liczby poszkodowanych. Rozpoczęto zatem organizowanie opieki pastoralnej nad uciekinierami z Prus Wschodnich, pomagano pozostającym na miejscu rodzinom, sierotom, wdowom, osobom przebywającym w lazaretach, szpitalach czy na froncie. Pomoc charytatywną ukierunkowano zarówno na cele parafialne i pozaparafialne, a zwłaszcza na rzecz inwalidów wojennych, czy też duszpasterstwa polowego. Dzięki stowarzyszeniom ewangelickim wrastała liczba wiernych zaangażowanych w niesienie pomocy potrzebującym. Kościół ewangelicki współpracował również z władzami państwowymi przy nadzwyczajnych akcjach społecznych i logistycznych, dotyczących np. zbiórki złota, metalu, ubrań oraz udostępniania obiektów kościelnych na cele wojenne.

Słowa kluczowe: I wojna światowa; uchodźcy; Kościół ewangelicki; Prusy Wschodnie; Niemcy w pierwszej połowie XX wieku; stowarzyszenia kościelne.

Abstract. Activity of the Evangelical Church in East Prussia during World War I. During World War I the Evangelical Church faced new challenges. The pastoral 
care was no longer limited to the promotion and supervision of religious and sacramental life in parishes. The decrease of population, material losses and deteriorating economic situation led to the necessity of the Church getting involved in causes for the benefit of the rapidly increasing number of people affected by the war. Therefore, pastoral care was organized for refugees from East Prussia. Those who had stayed - families, orphans, widows, people in hospitals and on the war front, received help. The charity assistance addressed issues within parishes as well as beyond them, most of all, it was targeted at war-disabled people and at field ministry. Thanks to Evangelical societies, the number of worshippers involved in giving help to those in need increased. The Evangelical Church also cooperated with state authorities in social actions and logistics, involving e.g. the collection of gold, metals, clothes, as well as making church buildings available for war-related purposes.

Keywords: World War I; refugees; Evangelical Church; East Prussia; Germany in the first half of the 20th century; Church societies.

I wojna światowa niosła za sobą destabilizację utrwalonego od dziesięcioleci porządku społeczno-politycznego. Wskutek zbrojnej kampanii wojsk nieprzyjacielskich, która przyczyniła się do zakwestionowania obowiązujących wcześniej reguł praworządności, Kościoły i związki wyznaniowe wydawały się ostoją zasad moralnych, stróżem poszanowania sprawiedliwości oraz gwarantem pomocy względem potrzebujących. Wymagało to od nich zaangażowania w wielu dziedzinach życia społecznego. W Prusach Wschodnich wyjątkową rolę w tym względzie odegrał Kościół ewangelicki (unijny), którego członkami była znakomita większość mieszkańców tej prowincji. W obliczu nowych wyzwań, opieka pastoralna nad wiernymi przestała ograniczać się do animowania życia sakramentalnego i religijnego w parafiach. Już w początkowym okresie wojennym istotne modyfikacje wprowadzono w porządek liturgicznych uroczystości. Organizowano zatem nabożeństwa upamiętniające wybuch wojny oraz jej trwanie. Modlono się w parafiach przy okazji powszechnej mobilizacji do wojska, w intencji poległych i in. Duszpasterską aktywność kierowano na dotknięte skutkami wojny rodziny, osoby przebywające w lazaretach, szpitalach oraz na froncie. Pomoc charytatywna przejawiała się z kolei organizowaniem zbiórek finansowych na cele parafialne oraz pozaparafialne (np. na rzecz uchodźców, inwalidów wojennych, zaopatrzenia żołnierzy $\mathrm{w}$ wydawnictwa religijne itp.). $\mathrm{W}$ tego rodzaju inicjatywy angażowały się 
szczególnie kobiety i dziewczęta. Dbano o młodzież, zakładano ośrodki zajmujące się pomocą dla dzieci, dokarmiano przechodzące oddziały wojskowe, a także udzielano wsparcia kalekom wojennym. Wśród innego rodzaju przedsięwzięć należy wymienić: upamiętnienie poległych żołnierzy, udzielanie pożyczek wojennych, współdziałanie z instytucjami państwowymi w organizowaniu nadzwyczajnych akcji społecznych i logistycznych, dotyczących np. zbiórki złota, metalu, ubrań oraz udostępniania obiektów kościelnych na cele wojenne ${ }^{1}$.

W historiografii na temat Kościoła ewangelickiego w Prusach Wschodnich w czasie I wojny światowej dominują publikacje niemieckojęzyczne z okresu wojennego i międzywojennego. Wśród współczesnej literatury należy wymienić nieocenioną monografię Waltera Hubatscha pt. Geschichte der evangelischen Kirche Ostpreussens ${ }^{2}$. Autor nakreślił sytuację tego Kościoła w trakcie wojny, a także wskazał główne pola jego działalności. Cenne informacje dotyczące tego zagadnienia, a zwłaszcza exodusu ludności wschodniopruskiej oraz ewangelickich zakładów opiekuńczych, przytoczył Grzegorz Jasiński³ ${ }^{3}$ Dotychczasowe opracowania nie wyczerpują jednak złożonej problematyki odnoszącej się do funkcjonowania Kościoła ewangelickiego w tym okresie. Z tego względu warto przeprowadzić analizę bogatego zasobu źródeł, zwłaszcza drukowanych. $\mathrm{Z}$ uwagi na ograniczone ramy tego artykułu, przytoczone wnioski będą miały raczej charakter prolegomenów do szerszej dysertacji na ten temat.

W sierpniu 1914 r., a zatem w początkowym etapie I wojny światowej, rosyjska ofensywa objęła swoim zasięgiem niemal całą prowincję wschodniopruską. Działania militarne nie dotknęły jedynie Królewca oraz

1 Uebersicht über besondere Betätigung der Kirche aus Anlaß des Krieges, „Amtliche Mitteilungen des Königlichen Konsistoriums der Provinz Ostpreußen“ 12 (1915), s. 60-61; zob. również Evangelischer Oberkirchenrat, Betrifft die Fürsorge für die Kriegsbeschädigten, „Amtliche Mitteilungen des Königlichen Konsistoriums der Provinz Ostpreußen“ 1915, nr 15, s. 75-77; Zur Mitarbeit der evangelischen Kirche an der Fürsorge für die Kriegsbeschädigten, „Evangelisches Gemeindeblatt“ 32 (1915), s. 137-139.

${ }^{2}$ W. Hubatsch, Geschichte der evangelischen Kirche Ostpreussens, t. 1, Göttingen 1968.

${ }^{3}$ G. Jasiński, Kościót ewangelicki w Prusach Wschodnich w latach 1817-1918, w: W 500-lecie Reformacji (1517-2017). Z dziejów Kościołów ewangelickich w dawnych Prusach Królewskich i Książęcych, t. 2, Tereny dawnych Prus Książęcych, red. J. Kłaczkow, G. Jasiński, P. Birecki, Toruń 2017, s. 240-245. 
części ziemskiego powiatu królewieckiego, który leżał na północ od Pregoły, a także powiatów Fischhausen, Pasłęk i Kłajpeda. W niewielkim stopniu szkody poniesiono w powiatach Święta Siekierka, Morąg i Heydekrug. $\mathrm{Z}$ obawy przed agresorem ludność cywilna ratowała się ucieczką. Zjawisko to przybrało masowy charakter. Fala migracji z Prus Wschodnich docierała nie tylko do Prus Zachodnich, ale również do prowincji pomorskiej, brandenburskiej, a nawet do Szlezwiku-Holsztyna, Meklemburgii, Hanoweru i Saksonii. Około 180 duchownych ewangelickich podjęło decyzję o ucieczce. Część z nich wyjechała wraz ze swoimi wspólnotami kościelnymi. Konsystorz królewiecki 12 sierpnia 1914 r., a zatem, jak się wydaje dość późno, nakłaniał duszpasterzy do nieopuszczania parafii. Apelował ponadto, aby kościoły były otwarte każdego dnia, w określonych godzinach. W czasie wojny miały one służyć nie tylko jako miejsce prywatnej, ale również dodatkowej, wspólnotowej modlitwy. W prowincji wschodniopruskiej pozostało około 140 duchownych, którzy byli w wielu przypadkach ostoją dla miejscowej ludności. Okazało się potem, że pozostający na miejscu mieszkańcy mogli ochronić swój dobytek materialny w przeciwieństwie do opustoszałych miejscowości, które stanowiły łatwą okazję do rabunku i plądrowania. Aktów wandalizmu dopuszczały się nie tylko wojska agresora, ale również rodzima ludność 4 .

Druga ofensywa wojsk rosyjskich na Prusy Wschodnie odbyła się na początku listopada 1914 r. Objęła ona swoim zasięgiem jedynie część prowincji, a mianowicie powiaty Piłkały, Stołupiany, Gąbin, Gołdap, Darkiejmy, Węgorzewo, Giżycko, Olecko, Ełk, Pisz, Mrągowo, Szczytno oraz Nidzica oraz leżące na północ od Niemna powiaty Tylża i Ragneta. Niektóre powiaty, znajdujące się na wschód od Węgorapy, zostały dotknięte działaniami militarnymi jedynie częściowo. Liczba wschodniopruskiej

${ }^{4}$ Das Königliche Konsistorium der Provinz Ostpreußen, An die evangelischen Geistlichen Ostpreußens, „Amtliche Mitteilungen des Königlichen Konsistoriums der Provinz Ostpreußen“ 11 (1914), s. 79-80; Der kirchliche Wiederaufbau Ostpreußens, "Gustav-Adolf-Bote für Ostpreußen“ 1-2 (1918), s. 5; por. W. Hubatsch, Geschichte der evangelischen Kirche Ostpreussens, s. 422; zob. również Evangelischer Oberkirchenrat, Erlaß des Evangelischen Oberkirchenrats betreffend Verhalten der Geistlichen der Provinz Ostpreußen bei der Invasion der Russen, „Amtliche Mitteilungen des Königlichen Konsistoriums der Provinz Ostpreußen“ 20 (1914), s. 115; G. Jasiński, Kościót ewangelicki w Prusach Wschodnich w latach 1817-1918, s. 240. 
ludności, ratująca się ucieczką, była tym razem znacznie wyższa niż kilka miesięcy wcześniej. Obawiano się, że ponowne natarcie Rosjan będzie charakteryzowało się większym okrucieństwem i przemocą. $Z$ tego względu miejscowa ludność opuściła swoje domostwa jeszcze przed przybyciem wojsk nieprzyjacielskich ${ }^{5}$. W czasie opisywanej ofensywy rosyjskiej około 120 duchownych przebywało poza swoim miejscem zamieszkania. Wśród nich była również część, która nie wróciła $\mathrm{z}$ migracji wskutek pierwszej ofensywy. Należy zaznaczyć, że żaden z duchownych nie poniósł śmierci $\mathrm{z}$ rąk agresora. Jedynie jeden został poważnie ranny, jednak po okresie hospitalizacji wrócił do zdrowia. Sześciu duchownych ewangelickich dostało się do rosyjskiej niewoli. Spośród nich dwóch powróciło w rodzinne strony $w$ następstwie wymiany jeńców. Jeden $z$ uprowadzonych księży, superintendent Friedrich Skierlo z Pisza, zmarł w Rosji w wieku 75 lat. Pozostałych trzech dzieliło dłużej losy jeńców: proboszcz Michael Schuischel z Nattkischken, Richard Fischer z Opaleńca i Ferdinand Otto Radtke z Dawillen. Z tym ostatnim wzięto do niewoli również precentora Knauera i dzwonnika Bandze z Dawillen. Dolę proboszcza Fischera podzielił z kolei organista Kloß z Opaleńca. W sierpniu 1914 r. zginęli z kolei kantor Hochwald z Abschwangen i organista Michaelis z Rogiedli ${ }^{6}$.

Powrót mieszkańców do wschodniopruskich miejscowości, okupowanych przez Rosjan do połowy września 1914 r. przebiegał łatwiej i szybciej niż na terenach znajdujących się we władaniu agresora od listopada 1914 r. do bitwy nad jeziorami mazurskimi, czyli do połowy lutego 1915 r. W pierwszym z przytoczonych okresów Rosjanie obchodzili się łagodniej wobec pruskiej własności prywatnej i publicznej, natomiast w drugim dopuszczano się zniszczeń na szeroką skalę. Wschodniopruska ludność, pozbawiona dobytku, często była skazana na życie w nędzy, dlatego władze państwowe rezerwowały sobie wydawanie pozwoleń na powrót do powiatów dotkniętych spustoszeniem. Przed dotarciem większej liczby mieszkańców starano się przywracać podstawowe warunki umożliwiające

${ }^{5}$ Der kirchliche Wiederaufbau Ostpreußens, s. 5-6.

6 Tamże, s. 6; J. Schneider, Kirchliche Zeitlage, w: Kirchliches Jahrbuch für die evangelischen Landeskirchen Deutschlands, opr. J. Schneider, Gütersloh 1916, s. 94; W. Hubatsch, Geschichte der evangelischen Kirche Ostpreussens, s. 423; Nachruf für Superintendent Skierlo-Johannisburg, „Königsberger Hartungsche Zeitung“ 121 (1916) z III 12; G. Jasiński, Kościót ewangelicki w Prusach Wschodnich w latach 1817-1918, s. 244. 
dalszą egzystencję. Duchowieństwu ewangelickiemu zgodę uprawniającą do powrotu na zajmowane wcześniej parafie wydawał konsystorz królewiecki. Oczywiście księży nie mogło zabraknąć w powiększających się liczebnie społecznościach. Ich opóźniające się przybycie było podyktowane tymczasowo przejętymi przez nich pozamiejscowymi obowiązkami bądź niekorzystnymi warunkami komunikacyjnymi. Należy dodać, że Ewangelicka Naczelna Rada Kościelna w Berlinie zagwarantowała większości duchownych zatrudnienie w innych prowincjach, a tym samym możliwość godziwego utrzymania ${ }^{7}$.

Od grudnia 1914 r. organizowano dla wschodniopruskich uchodźców szczególną duchową opiekę, zwłaszcza na terenach, na które dotarła znaczna ich liczba. Wytyczono w tym celu dziesięć obwodów, a mianowicie: Gdańsk, Szczecin, Koszalin, Poczdam, Frankfurt nad Odrą, Magdeburg, Lüneburg, Stade, Szlezwik-Holsztyn i Meklemburgia-Schwerin. Do każdego z nich został oddelegowany wschodniopruski ksiądz, aby w różnych miejscowościach gromadzić uchodźców, sprawować dla nich nabożeństwa i roztaczać nad nimi opiekę duszpasterską. Wprawdzie liczba migrantów znacznie przewyższała możliwości pastoralne duchowieństwa, jednak ten rodzaj opieki duchowej powszechnie traktowano jako dobrodziejstwo. Stanowiła ona formę pomocy w trudnym czasie pobytu na obcej ziemi oraz okazję do moralnego wsparcia ${ }^{8}$.

W czasie I wojny światowej, w duszpasterstwie polowym czynnie uczestniczyło 9 kapelanów wojskowych i 32 duchownych diecezjalnych z Prus Wschodnich ${ }^{9}$. Nad księżmi, którzy wskutek exodusu przebywali poza tą prowincją, szczególną opiekę roztoczyło Stowarzyszenie Księży Ewangelickich (Pfarrerverein). Organizacja ta wyasygnowała na ich rzecz 120 tys. marek, a także dostarczyła im liczne skrzynie z książkami, ubraniami i sprzętem domowym. Warto wspomnieć, że 14 wschodniopruskich

7 Der kirchliche Wiederaufbau Ostpreußens, s. 6; Kirchliche Tagesgeschichte, „Evangelisches Gemeindeblatt“ 39 (1914), s. 222; Aus der Provinz, „Evangelisches Gemeindeblatt“ 24 (1915), s. 106-107; Die Ostpreußischen Geistlichen in der Russenzeit, „Evangelisches Gemeindeblatt“ 51 (1917), s. 303-304.

${ }^{8}$ Aus der Provinz, „Evangelisches Gemeindeblatt“ 4 (1915), s. 19; Etwas über Seelsorge an den kriegsvertriebenen Ostpreußen, „Evangelisches Gemeindeblatt“ 14 (1915), s. 61-62; Der kirchliche Wiederaufbau Ostpreußens, s. 6-7.

${ }_{9}$ W. Hubatsch, Geschichte der evangelischen Kirche Ostpreussens, s. 424. 
księży ewangelickich (nie licząc kapelanów wojskowych), a wśród nich 4 superintendentów, uhonorowano żelaznym krzyżem w uznaniu ich wypróbowanej wierności (bewärte Treue) wobec ojczyzny ${ }^{10}$.

Z inicjatywy Ewangelickiej Naczelnej Rady Kościelnej w dniach 15-16 grudnia 1914 r. zorganizowano 14. Prowincjonalny Synod w Królewcu, w tamtejszym zamku. Kolejny synod odbył się w tym mieście w dniach 13-14 listopada 1917 r. Poza działalnością synodalną, regulującą istotne elementy funkcjonowania Kościoła ewangelickiego (unijnego) w prowincji, również Ewangelicki Konsystorz w Królewcu bez przeszkód wykonywał swoją pracę w okresie wojennym. Czynnie włączał się w działalność dobroczynną, aprowizację ludności, zakwaterowanie dzieci z dużych ośrodków miejskich, akcję zbiórki złota, a także pożyczki wojenne. Współorganizował pomoc na rzecz poszkodowanych oraz osieroconych wskutek wojny. Mimo niesprzyjającego czasu przeprowadzano ponadto wizytacje kościelne. W 1914 r. odbyło się ich 397, w 1915 r. - 434, w 1916 r. - 436, w 1917 r. - 445, zaś w 1918 r. - 456 ${ }^{11}$.

Zakrojone na szeroką skalę prace budowlane na obszarze prowincji wschodniopruskiej rozpoczęto jeszcze w trakcie wojny. Władze rządowe włączyły się w odbudowę zniszczonej infrastruktury kościelnej, a zwłaszcza budynków podlegających patronatowi państwowemu. Konsystorz królewiecki zarządził 14 września 1915 r., że poświęcenie oddanych do użytku świątyń, w których od dłuższego czasu nie sprawowano nabożeństw, bądź które otrzymały znaczące elementy wyposażenia, zarezerwowano generalnemu superintendentowi ${ }^{12}$.

Nieocenioną rolę $\mathrm{w}$ odbudowie życia religijnego w Prusach Wschodnich odegrały ośrodki i stowarzyszenia na rzecz misji wewnętrznych. Wschodniopruski Prowincjonalny Związek na rzecz Misji Wewnętrznych starał się ulżyć doli wspólnot kościelnych, pozbawionych duszpasterza w wyniku zawirowań wojennych. Duchowni należący do tego towarzystwa opiekowali się tymczasowo osieroconymi parafiami,

10 J. Schneider, Kirchliche Zeitlage, s. 94-95; Aus der Provinz, „Evangelisches Gemeindeblatt“ 33 (1915), s. 147.

11 Die 14. Ostpreußische Provinzialsynode, „Evangelisches Gemeindeblatt“ 51 (1914), s. 277-279; W. Hubatsch, Geschichte der evangelischen Kirche Ostpreussens, s. 427-428; G. Jasiński, Kościół ewangelicki w Prusach Wschodnich w latach 1817-1918, s. 243.

12 W. Hubatsch, Geschichte der evangelischen Kirche Ostpreussens, s. 426-427. 
a także pomagali przeciążonym obowiązkami księżom, wyręczając ich w głoszeniu kazań i celebracji nabożeństw ${ }^{13}$. Organizacja ta zajmowała się również zbiórką książek i czasopism na rzecz lazaretów, przekazywała kapelanom wojskowym, czy też posługującym w lazaretach, pisma przydatne w pracy duszpasterskiej, a także wydawała własnym sumptem publikacje wojenne. W czasie świąt Bożego Narodzenia 1914 r. rozkolportowała 25 tys. egzemplarzy „Weihnachtsgruß”. Od stycznia 1915 r. ukazywał się z kolei, nakładem 10 tys. egzemplarzy, „Sonntagsgruß für unsere Krieger”. Towarzystwo włączyło się aktywnie w opiekę nad uchodźcami. Pomagało szczególnie dzieciom, które straciły rodziców, organizując dla nich zakwaterowanie. Ponadto zajmowało się poszukiwaniem osób zaginionych w czasie wojny, rozprowadzaniem Pisma św., śpiewników i literatury dewocyjnej. Przejęło także kuratelę nad tak zwanymi dziećmi rosyjskimi (40 osób), które następnie umieszczono w rodzinach zastępczych. Opisywana organizacja roztoczyła ponadto opiekę nad owdowiałymi w czasie wojny kobietami. Nie bez znaczenia dla krzewienia wiary była również współpraca wspomnianego związku na rzecz misji wewnętrznych z 91 ewangelickimi towarzystwami robotniczymi i ludowymi, a zwłaszcza z Ewangelickim Związkiem Opieki nad Wschodniopruską Młodzieżą Żeńską (Evangelischer Verband zur Pflege der Weiblichen Jugend Ostpreußens) i Wschodniopruskim Prowincjonalnym Zrzeszeniem Ewangelickich Towarzystw Młodzieży Męskiej (Ostpreußischer Provinzialverband der Evangelischen Jünglingsvereine). W parafiach ewangelickich sprawowano opiekę nad młodzieżą męską w porozumieniu $\mathrm{z}$ organizacjami państwowymi ${ }^{14}$.

Ewangelicki Związek Prasy w Prusach Wschodnich (Evangelischer Pressverband für Ostpreußen) dzięki wydawanym co tydzień drukom wojennym i kalendarzom (Vaterländisch-Sozialer Volkskalender für Ostpreußen) wspierał morale ludności, która w czasie ofensywy rosyjskiej pozostała w swoich domach. Publikacje te zawierały m.in. treści religijne. W okresie wojennym ożywienie działalności przeżywały towarzystwa zrzeszające kobiety. Konieczność współpracy tych organizacji skutkowała

13 Der kirchliche Wiederaufbau Ostpreußens, s. 7; zob. także Kirchliche Liebestätigkeit im Kriege, „Evangelisches Gemeindeblatt“ 33 (1914), s. 193-194; Aus Königsberg, „Evangelisches Gemeindeblatt“ 29 (1915), s. 127-128.

${ }^{14}$ Der kirchliche Wiederaufbau Ostpreußens, s. 7. 
niejednokrotnie ich fuzją. W czasie działań wojennych nabrało rozgłosu zaangażowanie ich członkiń w akcje dobroczynne. Odbywające się regularnie wieczory wojenne dla kobiet służyły ich umocnieniu religijnemu. Złotymi zgłoskami w historiografii wojennej zapisało się zwłaszcza Towarzystwo Pomocy Kobiet (Frauenhilfe), które koncentrowało się w swojej działalności na łagodzeniu trudnej sytuacji gospodarczej i duchowej wśród wschodniopruskiej ludności. Osoby należące do niego włączały się $\mathrm{w}$ większych miastach $\mathrm{w}$ realizację akcji pomocowych, organizowanych zarówno przez administrację szczebla ogólnopaństwowego, jak też municypalnego, m.in. na rzecz kobiet dotkniętych skutkami wojny. Warto zaznaczyć, że w tym czasie Towarzystwo Pomocy Kobiet przysposobiło do zawodu około 300 osób zajmujących się opieką nad dziećmi i młodzieżą, chorymi czy też pracą socjalną w parafiach. Wspólnoty kościelne, które znacznie ucierpiały w wyniku pożogi wojennej, były wspomagane z kolei przez bratnie parafie $z$ innych regionów kraju, które roztaczały nad nimi szczególny patronat. Zaangażowanie kobiet $\mathrm{w}$ ten rodzaj pomocy było również nie do przecenienia ${ }^{15}$.

Szczególnego wsparcia w czasie I wojny światowej udzielały diakonise. Aż 417 sióstr z Domu Macierzystego Diakonis i prowadzonego przez nie Szpitala Miłosierdzia w Królewcu zaangażowało się w opiekę nad rannymi. Poza frontem posługiwały one $\mathrm{w}$ różnych rejonach Prus Wschodnich i Zachodnich, w Polsce, Rosji, Rumunii, a nawet w północnej Francji. W wymienionym na końcu regionie dostały się na dłuższy czas do niewoli. W czasie ofensywy rosyjskiej 250 sióstr, posługujących w 80 miejscowościach, wpadło w ręce wroga. Jeden z oddziałów sanitarnych Rosjanie uprowadzili aż do Sankt Petersburga. Tam jednak siostry mogły opiekować się rannymi żołnierzami niemieckimi. Zaangażowały się również w opiekę nad uchodźcami. Podkreślenia wymaga pomoc poszkodowanym w czasie wojny, której udzielały siostry z Mazurskiego Domu Macierzystego Diakonis „Bethanien” w Giżycku. Już w pierwszej połowie

15 Tamże, s. 7-8; por. W. Hubatsch, Geschichte der evangelischen Kirche Ostpreussens, s. 429; zob. również Das Königliche Konsistorium der Provinz Ostpreußen, An die evangelischen Geistlichen Ostpreußens, s. 80; Kirchliche Liebestätigkeit im Kriege, „Evangelisches Gemeindeblatt“ 33 (1914), s. 194; Frauenarbeit im Kriege. II, „Evangelisches Gemeindeblatt“ 27 (1915), s. 117-118; Frauenarbeit im Kriege. III, „Evangelisches Gemeindeblatt“ 31 (1915), s. 133-134. 
sierpnia 1914 r. 19 z nich pielęgnowało rannych nieopodal ich miejsca zamieszkania (Heimat). Dalszych 10 sióstr posłano w drugim roku wojny do zamiejscowych lazaretów. Kiedy Giżycko było bezpośrednio zagrożone przez Rosjan, 50 osób starszych i słabych, a także 30 dzieci uchodźców przyjęto do ich domu. W najcięższych dniach siostry dawały schronienie nawet 130 uchodźcom dziennie ${ }^{16}$.

Niemiecko-rosyjskimi repatriantami z dotkniętych wojną obszarów Wołynia (około 5000 osób tylko na początku 1916 r.), którzy znaleźli schronienie w Prusach Wschodnich, zaopiekowało się, z polecenia nadprezydenta wschodniopruskiego, Ewangelicko-Kościelne Towarzystwo Pomocy (Evangelisch-Kirchlicher Hilfsverein). Do posługi nad tą ludnością został oddelegowany jeden z duchownych. Chodziło prawdopodobnie o pastora Groundstroema. Z kolei proboszcz Paul Lenkeit z Królewca-Starego Miasta udzielał lekcji konfirmantom wołyńskim, których część była analfabetami ${ }^{17}$.

Z inicjatywy Ewangelickiej Komisji Kościelnej w Niemczech zwołano w ewangelickich Kościołach na obszarze całego państwa zbiórkę na rzecz prowincji wschodniopruskiej, dotkniętej reperkusjami I wojny światowej. Znakomitą część zgromadzonych środków finansowych przekazano konsystorzowi królewieckiemu ${ }^{18}$, o czym informuje poniższa tabela.

Tab. 1. Fundusze przekazane konsystorzowi królewieckiemu w ramach zbiórki zorganizowanej przez ewangelickie Kościoły w Niemczech do 1 października $1917 \mathrm{r}$.

\begin{tabular}{|c|c|}
\hline Rejon kościelny & $\begin{array}{c}\text { Wartość przekazanej kwoty finansowej } \\
\text { (w markach) }\end{array}$ \\
\hline Prusy, tzw. starsze prowincje & 430075,12 \\
\hline
\end{tabular}

${ }^{16}$ Der kirchliche Wiederaufbau Ostpreußens, s. 8; Diakonissenarbeit im Etappengebiet, „Evangelisches Gemeindeblatt“ 41 (1914), s. 233-234; Diakonissenarbeit unter Feindeshand, „Evangelisches Gemeindeblatt“ 20 (1915), s. 89-90; W. Hubatsch, Geschichte der evangelischen Kirche Ostpreussens, s. 424-425; zob. również Diakonissenarbeit unter Feindeshand, „Evangelisches Gemeindeblatt“ 39 (1914), s. 221-222.

17 Der kirchliche Wiederaufbau Ostpreußens, s. 8.

18 Tamże, s. 10. Całkowita kwota finansowa zgromadzona w czasie ogólnoniemieckiej zbiórki wynosiła 1050 045,95 marek; zob. tamże, s. 11. 
Tab. 1. cd.

\begin{tabular}{|c|c|}
\hline Rejon kościelny & $\begin{array}{l}\text { Wartość przekazanej kwoty finansowej } \\
\text { (w markach) }\end{array}$ \\
\hline Prusy, tzw. nowe prowincje: & \multirow{7}{*}{142520,88} \\
\hline $\begin{array}{l}\text { a. Hanower, Kościół luterański (66 809,21 } \\
\text { marek) }\end{array}$ & \\
\hline $\begin{array}{l}\text { b. Hanower, Kościół reformowany } \\
\text { (14 110,83 marki) }\end{array}$ & \\
\hline c. Szlezwik-Holsztyn (26 226,52 marki) & \\
\hline $\begin{array}{l}\text { d. Rejon kościelny Kassel (18 217,63 } \\
\text { marki) }\end{array}$ & \\
\hline $\begin{array}{l}\text { e. Rejon kościelny Wiesbaden (13 244,94 } \\
\text { marki) }\end{array}$ & \\
\hline $\begin{array}{l}\text { f. Rejon kościelny Frankfurt nad Menem } \\
(3911,75 \text { marek })\end{array}$ & \\
\hline $\begin{array}{l}\text { Bawaria, rejon Protestanckiego } \\
\text { Nadkonsystorza w Monachium }\end{array}$ & 140676,30 \\
\hline Saksonia & 61506,14 \\
\hline Wirtembergia & 66156,60 \\
\hline Badenia & 48575,60 \\
\hline Hesja & 17643,75 \\
\hline Oldenburg: & \multirow{3}{*}{8599,27} \\
\hline $\begin{array}{l}\text { a. Rejon Ewangelickiej Naczelnej Rady } \\
\text { Kościelnej w Oldenburgu }(7427,27 \\
\text { marek) }\end{array}$ & \\
\hline b. Księstwo Birkenfeld (1172 marki) & \\
\hline Meklemburgia-Schwerin & 21185,55 \\
\hline Anhalt & 3902,69 \\
\hline Saksonia-Altenburg & 1731,13 \\
\hline Saksonia-Coburg & 561,90 \\
\hline Reuß linii starszej & 2062,48 \\
\hline Reuß linii młodszej & 704,83 \\
\hline Schwarzburg-Rudolstadt & 1657 \\
\hline Schwarzburg-Sonderhausen & 1649,54 \\
\hline Lippe & 7271,47 \\
\hline Schaumburg-Lippe & 2636,51 \\
\hline Waldeck & 5665,89 \\
\hline $\begin{array}{c}\text { Alzacja-Lotaryngia, Kościoły konfesji } \\
\text { augsburskiej }\end{array}$ & 13558,10 \\
\hline Suma: & 978340,75 \\
\hline
\end{tabular}

Źródło: Der kirchliche Wiederaufbau Ostpreußens, „Gustav-Adolf-Bote für Ostpreußen“ 1-2 (1918), s. 10. 
Konsystorz królewiecki otrzymał do 1 października 1917 r. kwotę finansową o wartości 978 340,75 marek. Najwięcej pieniędzy przekazano z tzw. starszych prowincji pruskich $(430$ 075,12), a najmniej z Saksonii-Coburg (jedynie 561,90 marek) ${ }^{19}$.

Otrzymanym ze zbiórki kapitałem miał rozporządzać konsystorz królewiecki w porozumieniu z zarządem synodu prowincjonalnego i nadprezydentem prowincji wschodniopruskiej. W początkowym okresie pieniądze te przeznaczano na łagodzenie trudnej sytuacji, w jakiej znaleźli się członkowie Kościoła ewangelickiego. Przede wszystkim starano się ulżyć uciekającej przed ofensywą rosyjską ludności, finansując opiekę pastoralną nad tymi wiernymi. Kolejną część funduszy przekazano na rzecz tzw. proboszczów stacyjnych (Stationspfarrer), oddelegowanych do opieki duchowej nad osobami, które pozostały w zagrożonej bezpośrednio działaniami militarnymi strefie, mimo wcześniej zarządzonej ewakuacji. Po wyparciu Rosjan z Prus Wschodnich dotowano z tego funduszu różnorodne wydatki służące przywróceniu życia religijnego oraz właściwego duszpasterstwa w Prusach Wschodnich. Opłacono m.in. zakup egzemplarzy Biblii, pobożnych lektur i śpiewników na rzecz zrujnowanych materialnie parafii. Zapotrzebowanie na tego rodzaju literaturę zgłaszali ponadto uchodźcy przebywający poza prowincją. Dzięki opisywanej zbiórce wypłacano pensje również duchownym, którzy podjęli się zastępstwa za wziętych do niewoli rosyjskiej superintendentów i proboszczów. Fundusze te służyły wreszcie adaptacji oraz budowie zastępczych miejsc celebracji liturgicznych ${ }^{20}$.

Dość sprawne przekazanie do użytku miejscowym wspólnotom kościelnym zastępczych pomieszczeń, gdzie odbywały się nabożeństwa,

19 Zob. również Evangelischer Oberkirchenrat, Kundgebung des Evangelischen Oberkirchenrats an die Provinzialsynode, „Amtliche Mitteilungen des Königlichen Konsistoriums der Provinz Ostpreußen“ 20 (1914), s. 116.

${ }^{20}$ Der kirchliche Wiederaufbau Ostpreußens, s. 10. Warto nadmienić, że wiosną 1915 r. minister finansów zadeklarował pomoc na rzecz parafii ewangelickich, które w wyniku ataku wojsk rosyjskich stały się niewypłacalne. Miała ona dotyczyć regulacji pilnych zobowiązań finansowych; zob. R. Kähler, Kriegsschäden der Kirchengemeinden und Geistlichen, „Amtliche Mitteilungen des Königlichen Konsistoriums der Provinz Ostpreußen“ 6 (1915), s. 29. 
posiadało niewątpliwie charakter propagandowy oraz budowało morale wiernych. Tytułem egzemplifikacji warto wskazać parafię ewangelicką w Nidzicy. Wskutek ofensywy rosyjskiej 22 sierpnia 1914 r. ogień strawił sięgający średniowiecza, ale wielokrotnie odbudowywany i przebudowywany kościół w tym mieście, poświęcony w 1819 r. Z powodu braku innego, odpowiedniego pomieszczenia, w drugiej połowie 1914 r. nabożeństwa sprawowano w miejskiej hali sportowej. Z historii tej świątyni wynika, że odbudowa po każdorazowej pożodze trwała dość długo. Po jej spaleniu w 1664 r. cegły na jej odbudowę ufundowano dopiero w 1689 r., zaś po analogicznym wydarzeniu z 1805 r. na poświęcenie czekano 14 lat. Dzięki jednak staraniom zarówno nidzickiej wspólnoty parafialnej, jak też konsystorza królewieckiego i władz państwowych, 1 kwietnia 1916 r. prezydent wspomnianego konsystorza osobiście przekazał wiernym wiadomość, że przyznano fundusze na tymczasowy obiekt sakralny. Opracowania jego projektu, zresztą nieodpłatnie, podjął się profesor Bodo Heinrich Justus Ebhardt z Berlina. Prowizoryczną świątynię wzniesiono jako dobudowę do domu parafialnego, który ukończono na początku I wojny światowej. Struktura tych dwóch obiektów umożliwiała późniejsze ich zespolenie i adaptację tymczasowej przestrzeni sakralnej na salę spotkań w domu parafialnym. W tym celu planowano zrównać poziom podłogi nowego obiektu kościelnego z głównym piętrem domu parafialnego, ale niestety zabrakło na to środków finansowych. Postarano się jednak o dobrą komunikację świątyni z domem parafialnym. Na zewnątrz nowy obiekt sakralny nie sprawiał wrażenia budowli prowizorycznej. Oczywiście zrezygnowano z użycia jakichkolwiek elementów, które byłyby zbyteczne. Na początku dysponowano bowiem kapitałem o wartości 25 tys. marek na jego budowę. Później wzrósł on do 35 tys. marek. Wnętrze tej tymczasowej świątyni posiadało 22 metry długości i 11 metrów szerokości. Przekryto ją drewnianym, ostrołukowym sklepieniem beczkowym, które opierało się na jednolitych, drewnianych wiązarach. Dzięki temu zrezygnowano z nawarstwienia drewnianych elementów konstrukcyjnych w jej wnętrzu, przez co sprawiało ono godne i odświętne wrażenie. Wymalowano je również dość skromnie. Ambonę usytuowano za ołtarzem. W tej prowizorycznej świątyni znajdowało się 500 miejsc siedzących i 250 stojących. Budową kierowało Towarzystwo na rzecz Architektury Niemieckiej z Berlina 
(Gesellschaft für deutsche Baukunst Berlin), które posiadało w Nidzicy swój oddział ${ }^{21}$.

I wojna światowa stała się przyczyną ustanowienia nadzwyczajnych nabożeństw we wschodniopruskich parafiach. Gromadzono się na wspólnych modlitwach po zwycięskiej bitwie nad jeziorami mazurskimi. Nadzwyczajną rangę posiadało również nabożeństwo przebłagalne w intencji zbiorów, ustanowione na Niedzielę Rogate (9 maja 1915 r.). Pierwsza rocznica wybuchu wojny (1 sierpnia 1915 r.) stała się z kolei okazją do celebrowania nabożeństw, w których wspominano dotychczasową Bożą pomoc i opiekę. Odświętne nabożeństwo odprawiano również 24 października 1915 r. z okazji pięćsetnej rocznicy władania Hohenzollernów²2.

W czasie Święta Zmarłych obchodzonego bez mała po raz setny w 1915 r. (pierwszy raz celebrowano tę uroczystość w 1816 r. na pamiątkę poległych na frontach wojennych w latach 1813-1815), wspominano ofiary I wojny światowej, zresztą przy licznym udziale wiernych ${ }^{23}$. Władze kościelne włączyły się również w inicjatywę uczczenia poległych żołnierzy. Starano się przy tym unikać form upamiętniających, które godziły $\mathrm{w}$ pietyzm i dobry smak artystyczny (np. umieszczanie w świątyniach fotografii rodzinnych po zmarłym). Ewangelicka Naczelna Rada Kościelna w Berlinie nawiązała współpracę z kompetentnymi instytucjami w celu pozyskania wartościowych projektów tablic kommemoratywnych i pamiątkowych rzeźb kamiennych. Zarządzono również, aby poszczególne parafie wstrzymały się z realizacją ewentualnych projektów dotyczących uhonorowania poległych żołnierzy do zakończenia wojny. Oczywiście nie ingerowano $\mathrm{w}$ inicjatywy odnoszące się do translokacji ciał tych zmarłych, czy też uwiecznienia pamięci o nich na cmentarzach. W mniejszych wspólnotach parafialnych wyczytywano nazwiska poległych w czasie nabożeństwa. Niemal bez wyjątku ich nekrologi umieszczano w gazetkach parafialnych. Każdą parafię zobowiązano ponadto do założenia kroniki

${ }^{21}$ Erbauung und Weihe der Notkirche in Neidenburg, „Gustav-Adolf-Bote für Ostpreußen“ 7-8 (1918), s. 45.

${ }^{22}$ Kirchliche Tagesgeschichte, „Evangelisches Gemeindeblatt“ 41 (1915), s. 178; Zum Hohenzollerntag, „Evangelisches Gemeindeblatt“ 43 (1915), s. 185-186; J. Schneider, Kirchliche Zeitlage, s. 83; W. Hubatsch, Geschichte der evangelischen Kirche Ostpreussens, s. 428 .

${ }^{23}$ J. Schneider, Kirchliche Zeitlage, s. 83. 
wojennej, w której odnotowywano charakterystyczne wydarzenia z życia wspólnoty wiernych i doświadczenia jej członków ${ }^{24}$.

Czterystuletni jubileusz Reformacji świętowano we wszystkich ewangelickich parafiach prowincji bez szczególnego aplauzu. Z tej okazji celebrowano jedynie nabożeństwa, organizowano wykłady, muzyczne koncerty, itp. Na pamiątkę jej obchodów został erygowany w stolicy prowincji wschodniopruskiej Dom Lutra, przeznaczony dla studentów teologii. Jego początkowy kapitał opiewał na 40 tys. marek. W królewieckim zamku wygłoszono cykl kazań pt. Co zawdzięczamy Reformacji? Miejscowy uniwersytet nadał z tej okazji honorowe doktoraty. 31 października odbyło się w tamtejszej katedrze uroczyste nabożeństwo z udziałem władz państwowych, miejskich i uniwersyteckich. Kazanie wygłosił generalny superintendent Paul Johannes Gennrich ${ }^{25}$.

Kościół ewangelicki (unijny) w Prusach Wschodnich odegrał szczególną rolę w czasie I wojny światowej. Dotychczasowe formy opieki pastoralnej zostały znacznie poszerzone o doświadczenia, jakie niósł za sobą teatr działań wojennych. Ubytek ludności, straty materialne, czy też pogarszająca się sytuacja gospodarcza wygenerowały konieczność zaangażowania na rzecz gwałtowanie wzrastającej liczby poszkodowanych. Nowe inicjatywy duszpasterskie, uczestnictwo w towarzystwach niosących pomoc potrzebującym, czy też współpraca z organami państwowymi $\mathrm{w}$ przywracaniu porządku społecznego, przyczyniły się z pewnością do zniwelowania skutków zawieruchy wojennej. Wsparcie ze strony Kościoła udzielane wschodniopruskiej ludności było szansą na ożywienie życia religijnego, a także dodawało otuchy i nadziei na lepszy czas.

${ }^{24}$ Tamże, s. 93; zob. również Evangelischer Oberkirchenrat, Erlaß des Evangelischen Oberkirchenrates, betreffend Einrichtung und Führung von Kriegschroniken durch die Herren Geistlichen, „Amtliche Mitteilungen des Königlichen Konsistoriums der Provinz Ostpreußen“ 9 (1915), s. 41; Evangelischer Oberkirchenrat, Kirchliche Ehrung der Gefallenen, „Amtliche Mitteilungen des Königlichen Konsistoriums der Provinz Ostpreußen“ 9 (1915), s. 42-43.

${ }^{25}$ W. Hubatsch, Geschichte der evangelischen Kirche Ostpreussens, s. 429-430. 


\section{BIBLIOGRAFIA}

Aus der Provinz, „Evangelisches Gemeindeblatt“ 24 (1915), s. 106-107.

Aus der Provinz, „Evangelisches Gemeindeblatt“ 4 (1915), s. 19.

Aus Königsberg, „Evangelisches Gemeindeblatt“ 29 (1915), s. 127-128.

Das Königliche Konsistorium der Provinz Ostpreußen, An die evangelischen Geistlichen

Ostpreußens, „Amtliche Mitteilungen des Königlichen Konsistoriums der Provinz Ostpreußen“ 11 (1914), s. 79-80.

Der kirchliche Wiederaufbau Ostpreußens, „Gustav-Adolf-Bote für Ostpreußen“ 1-2 (1918), s. 5-11.

Diakonissenarbeit im Etappengebiet, „Evangelisches Gemeindeblatt“ 41 (1914), s. 233-234.

Diakonissenarbeit unter Feindeshand, „Evangelisches Gemeindeblatt“ 39 (1914), s. 221222.

Diakonissenarbeit unter Feindeshand, „Evangelisches Gemeindeblatt“ 20 (1915), s. 89-90.

Die 14. Ostpreußische Provinzialsynode, „Evangelisches Gemeindeblatt“ 51 (1914), s. $277-279$.

Die Ostpreußischen Geistlichen in der Russenzeit, „Evangelisches Gemeindeblatt“ 51 (1917), s. 303-304.

Erbauung und Weihe der Notkirche in Neidenburg, „Gustav-Adolf-Bote für Ostpreußen“ 7-8 (1918), s. 45.

Etwas über Seelsorge an den kriegsvertriebenen Ostpreußen, „Evangelisches Gemeindeblatt“ 14 (1915), s. 61-62.

Evangelischer Oberkirchenrat, Betrifft die Fürsorge für die Kriegsbeschädigten, „Amtliche Mitteilungen des Königlichen Konsistoriums der Provinz Ostpreußen“ 15 (1915), s. $75-77$.

Evangelischer Oberkirchenrat, Erlaß des Evangelischen Oberkirchenrates, betreffend Einrichtung und Führung von Kriegschroniken durch die Herren Geistlichen, „Amtliche Mitteilungen des Königlichen Konsistoriums der Provinz Ostpreußen“ 9 (1915), s. 41.

Evangelischer Oberkirchenrat, Erlaß des Evangelischen Oberkirchenrats betreffend Verhalten der Geistlichen der Provinz Ostpreußen bei der Invasion der Russen, „Amtliche Mitteilungen des Königlichen Konsistoriums der Provinz Ostpreußen“ 20 (1914), s. 115.

Evangelischer Oberkirchenrat, Kirchliche Ehrung der Gefallenen, „Amtliche Mitteilungen des Königlichen Konsistoriums der Provinz Ostpreußen“ 9 (1915), s. 42-43.

Evangelischer Oberkirchenrat, Kundgebung des Evangelischen Oberkirchenrats an die Provinzialsynode, „Amtliche Mitteilungen des Königlichen Konsistoriums der Provinz Ostpreußen“ 20 (1914), s. 116.

Frauenarbeit im Kriege. II, „Evangelisches Gemeindeblatt“ 27 (1915), s. 117-118. Frauenarbeit im Kriege. III, „Evangelisches Gemeindeblatt“ 31 (1915), s. 133-134. Hubatsch W., Geschichte der evangelischen Kirche Ostpreussens, t. 1, Göttingen 1968. 
Jasiński G., Kościół ewangelicki w Prusach Wschodnich w latach 1817-1918, w: W 500-lecie Reformacji (1517-2017). Z dziejów Kościołów ewangelickich w dawnych Prusach Królewskich i Książęcych, t. 2, Tereny dawnych Prus Książęcych, red. J. Kłaczkow, G. Jasiński, P. Birecki, Toruń 2017, s. 139-245.

Kähler R., Kriegsschäden der Kirchengemeinden und Geistlichen, „Amtliche Mitteilungen des Königlichen Konsistoriums der Provinz Ostpreußen“ 6 (1915), s. 29.

Kirchliche Liebestätigkeit im Kriege, „Evangelisches Gemeindeblatt“ 33 (1914), s. 193-194.

Kirchliche Tagesgeschichte, „Evangelisches Gemeindeblatt“ 39 (1914), s. 222.

Kirchliche Tagesgeschichte, „Evangelisches Gemeindeblatt“ 41 (1915), s. 178.

Nachruf für Superintendent Skierlo-Johannisburg, „Königsberger Hartungsche Zeitung“ 121 (1916) z III 12.

Schneider J., Kirchliche Zeitlage, w: Kirchliches Jahrbuch für die evangelischen Landeskirchen Deutschlands, opr. J. Schneider, Gütersloh 1916, s. 27-191.

Uebersicht über besondere Betätigung der Kirche aus Anlaß des Krieges, „Amtliche Mitteilungen des Königlichen Konsistoriums der Provinz Ostpreußen“ 12 (1915), s. $60-61$.

Zum Hohenzollerntag, „Evangelisches Gemeindeblatt“ 43 (1915), s. 185-186.

Zur Mitarbeit der evangelischen Kirche an der Fürsorge für die Kriegsbeschädigten, „Evangelisches Gemeindeblatt“ 32 (1915), s. 137-139. 